Diklus: Jurnal Pendidikan Luar Sekolah, 1(1), Maret 2017 - 64

Anggrita Kusumaninggar

\title{
DAMPAK PELAKSANAAN PROGRAM PENDIDIKAN KECAKAPAN HIDUP MENJAHIT TERHADAP AKTIVITAS WIRAUSAHA WARGA BELAJAR DI LEMBAGA KURSUS DAN PELATIHAN (LKP) AR-RUM YOGYAKARTA
}

\section{THE EFFECT OF IMPLEMENTATION SKILL LIFE SEWN EDUCATION PROGRAMME TO THE INDUSTRIALIST ACTIVITY OF CITIZEN LEARNAT COURSE AND TRAINING ORGANIZATION (LKP) AR-RUM YOGYAKARTA}

Oleh : Anggrita Kumidaninggar, Pendidikan Luar Sekolah, anggritakumidaninggar@gmail.com

\begin{abstract}
Abstrak
Penelitian ini bertujuan untuk mendeskripsikan: (1) Pelaksanaan program pendidikan kecakapan hidup menjahit (2) Hasil pelaksanaan program pendidikan kecakapan hidup menjahit. (3) Dampak pelaksanaan program pendidikan kecakapan hidup menjahit terhadap aktivitas wirausaha warga belajar. (4) Faktor yang mempengaruhi program pendidikan kecakapan hidup menjahit terhadap aktivitas wirausaha warga belajar. Penelitian ini menggunakan pendekatan kualitatif dengan metode deskriptif kualitatif. Informan penelitian yaitu pengelola, instruktur menjahit dan warga belajar pendidikan kecakapan hidup menjahit. Teknik pengumpulan data menggunakan observasi, wawancara dan dokumentasi. Teknik analisis data menggunakan reduksi data, display data, dan penarikan kesimpulan. Keabsahan data menggunakan trianggulasi sumber. Hasil penelitian ini diantaranya yaitu : (1) Pelaksanaan program pendidikan kecakapan hidup menjahit di LKP AR-RUM (2) Hasil pelaksanaan program pendidikan kecakapan hidup menjahit mencakup peningkatan pengetahuan, hasil produk, kecakapan personal, kecakapan sosial, kecakapan akademik, dan kecakapan vokasioanal. (3) Dampak ekonomi program pendidikan kecakapan hidup menjahit yaitu berkurangnya jumlah pengeluaran. Sedangkan dampak sosial yaitu perubahan perilaku, keterampilan, sikap, pengetahuan, status atau perubahan sosial, dan interaksi sosial warga belajar terhadap orang lain dan masyarakat luas. (4) Faktor pendukung yaitu adanya sarana prasarana yang lengkap, instruktur yang berkompeten dan pengalaman, situasi dan lingkungan yang kondusif. Faktor penghambat yaitu usia warga belajar yang berbeda, kemampuan instruktur yang kurang maksimal, dan kemampuan warga belajar yang berbeda, tidak adanya keberanian untuk membuka usaha, dan tidak adanya dana untuk membuka usaha.
\end{abstract}

Kata kunci : hasil program PKH, dampak program $P K H$, faktor $P K H$

\begin{abstract}
This research is aimed to describe: 1) How Sewing Education Life Skill Program held at LKP AR-RUM. 2) The result of Sewing Education Life Skill Program. 3) The impacts of Sewing Education Life Skill Program. 4) Stimulated factors of Sewing Education Life Skill Program. Qualitative approach is applied to this research by using descriptive qualitative method. Subject of this research are LKP AR-RUM administrator, instructor, and sewing education life skill program member. The data were collected by observation, interview, and documentation. The data were analyzed by data reduction, data display, and conclusion. Triangulation was applied to establish the trustworthiness of the data. The results of the research are: 1) Sewing Education Life Skill Program held at LKP AR-RUM. 2) Results of sewing education life skill program covered the increase of knowledge, product results, personal skill, social skill, academic skill, and vocational skill. 3) The economic impacts of sewing education life skill program are less expenditure. Whereas the social impacts are social changes at their behavior, skill, attitude, knowledge, social status, and sewing education life skill program member's interaction to other people and wide people. 4) Supported factors are experienced instructor and conducive situation and atmosphere. Obstacle factors are different age of the member; instructors are less optimal on taking care of the member, and member's different ability to learn.
\end{abstract}




\section{Diklus: Jurnal Pendidikan Luar Sekolah, 1(1), Maret 2017 - 65 \\ Anggrita Kusumaninggar}

Keyword: Life Skill Program results, Life Skill Program effects, Life Skill Program factor

\section{PENDAHULUAN}

Pendidikan adalah usaha sadar dan terencana untuk mewujudkan suasana belajar dan proses pembelajaran agar warga belajar secara aktif mengembangkan potensi dirinya untuk memiliki kekuatan spiritual keagamaan, pengendalian diri, kepribadian, kecerdasan, akhlak mulia, serta keterampilan yang diperlukan dirinya, masyarakat, bangsa dan negara (UU No. 20 tahun 2003 pasal 1 ayat 1). Kualitas pendidikan merupakan salah satu indikator peningkatan Sumber Daya Manusia (SDM) di sebuah negara. Dengan terselenggaranya program-program dibidang pendidikan yang berkualitas maka akan berdampak positif terhadap produktivitas SDM.

Perkembangan informasi dan teknologi saat ini menuntut Sumber Daya Manusia (SDM) yang berkualitas agar mampu bersaing dalam pasar kerja global dan pengembangan sistem pendidikan sangat diperlukan untuk mendukung kualitas Sumber Daya Manusia (SDM). Namun pada kenyataannya, tingkat pendidikan masyarakat di Indonesia masih dalam taraf rendah dan sebagian besar angkatan kerja di Indonesia masih dalam keadaan menganggur.

Selain itu, pemerataan pendidikan juga harus ikut andil di dalam mewujudkan masyarakat yang sadar bahwa pendidikan itu sangatlah penting. Pendidikan juga akan mengarahkan masyarakat untuk bersaing dalam dunia kerja dan membangun peradaban yang lebih baik. Dengan melihat tingkat persaingan hidup yang semakin hari semakin sulit, maka banyak hal yang harus perlu untuk disiapkan dan dibekali pada diri kita sehingga tidak mengalami kesulitan hidup, dan pada saat itulah mulai dirasakan pentingnya dunia wirausaha untuk mengurangi jumlah pengangguran.

Begitu halnya fenomena yang terjadi di wilayah D.I Yogyakarta, menurut data yang diperoleh dari Badan Pusat Statistik jumlah penduduk usia bekerja atau usia 15 tahun keatas di D.I Yogyakarta pada bulan Agustus 2015 mencapai 2,883 juta orang, mengalami peningkatan sebanyak $1,24 \%$ dibanding keadaan pada bulan Agustus 2014 sebanyak 2,848 juta orang atau bertambah 35,23 ribu orang. Jumlah penduduk angkatan kerja di D.I Yogyakarta pada bulan Agustus 2015 mencapai 1,971 juta orang, mengalami penurunan sebanyak 2,57\% dibanding angkatan kerja pada bulan Agustus 2014 sebanyak 2,023 juta orang, sedangkan jumlah penduduk yang bekerja di D.I Yogyakarta pada bulan Agustus 2015 mencapai 1,891 juta orang, mengalami penurunan sebanyak 3,31\% dibanding keadaan pada bulan Agustus 2014 sebanyak 1,956 juta orang (BPS Provinsi D.I Yogyakarta tahun 2015). Dengan melihat data tersebut dimana penduduk bukan angkatan kerja lebih banyak 


\section{Diklus: Jurnal Pendidikan Luar Sekolah, 1(1), Maret 2017 - 66 \\ Anggrita Kusumaninggar}

dibandingkan dengan penduduk yang menganggur.

Di wilayah Kota Yogyakarta jumlah pengangguran dari tahun ke tahun semakin meningkat hal ini disebabkan karena masih banyaknya masyarakat yang tingkat pendidikan dan keterampilannya masih dibawah standar minimal yang dibutuhkan oleh pasar kerja, akan tetapi masyarakat menginginkan pekerjaan yang dirasakan dapat membantu untuk menopang kehidupan mereka dengan mengingat rendahnya taraf kehidupan perekonomian masyarakat yang ada. Upaya dalam meningkatkan kualitas Sumber Daya Manusia (SDM) yang telah ditempuh selama ini dengan berbagai cara, diantaranya dengan meningkatkan pengetahuan, keterampilan, sikap dan kemampuan dengan berbagai cara, baik melalui pendidikan formal, pendidikan informal, maupun pendidikan non formal. Pendidikan non formal adalah usaha yang terorganisir secara sistematis dan kontinyu diluar sistem sekolah, melalui hubungan sosial untuk membimbing individu, kelompok, dan masyarakat agar memiliki sikap dan cita-cita sosial yang efektif guna meningkatkan taraf hidup dibidang material, sosial dan juga mental dalam rangka mewujudkan kesejahteraan sosial (Hamojoyo, 1973: vi).

Adapun fungsi dari pendidikan non formal sendiri yaitu sebagai penambah, pengganti ataupun pelengkap dari adanya pendidikan formal yang ada dalam rangka untuk mendukung pendidikan sepanjang hayat. Program yang diselenggarakan melalui pendidikan nonformal dimaksudkan untuk dapat melayani berbagai kebutuhan masyarakat yang karena suatu hal tidak dapat memperoleh kesempatan belajar di pendidikan formal.

Peraturan pemerintah No. 19 Tahun 2005 tentang Standar Nasional Pendidikan Nasional pasal 6 ayat 3 menjelaskan satuan pendidikan non formal dalam bentuk kursus atau lembaga pelatihan menggunakan kurikulum berbasis kompetensi yang memuat pendidikan kecakapan hidup dan keterampilan. Untuk itu masyarakat sangatlah perlu diberikan suatu keterampilan untuk membekali dirinya dan sangatlah perlu diberikan Pendidikan Kecakapan Hidup (Life Skills). Salah satu lembaga yang menyediakan Pendidikan Kecakapan Hidup yaitu Lembaga Kursus dan Pelatihan atau yang sering dikenal dengan sebutan LKP, yang merupakan sebuah lembaga pendidikan yang lahir dari pemikiran tentang kesadaran akan pentingnya kedudukan masyarakat Indonesia didalam proses pembangunan. Oleh sebab itu berdirinya LKP ditengah masyarakat diharapkan mampu menjadi tulang punggung bagi terjadinya proses pembangunan dengan melalui pemberdayaan potensi-potensi yang ada dimasyarakat.

Penyelenggaraan Program Pendidikan Kecakapan Hidup (life Skills) yang memegang 


\section{Diklus: Jurnal Pendidikan Luar Sekolah, 1(1), Maret 2017 - 67 \\ Anggrita Kusumaninggar}

peranan penting dalam membekali peserta didik untuk menguasai program pelatihan, maka peserta didik sangat dibebaskan memilih progam pendidikan kecakapan yang ingin dikembangkan sesuai dengan minatnya. Lembaga Kursus dan Pelatihan ini memiliki banyak kegiatan yang dapat menunjang kebutuhan masyarakat. Lembaga Kursus dan Pelatihan juga berperan aktif untuk memberikan program-program yang efektif untuk mengembangkan keterampilan yang dimiliki peserta sesuai dengan bakat dan minatnya. Keterlibatan Instruktur dan Pengelola sebagai pengantar sangatlah dibutuhkan untuk dapat menciptakan suasana yang harmonis dengan peserta didik. Life Skills dapat dilakukan pada di semuan jenjang didalam satuan Pendidikan Luar Sekolah. Pendidikan yang dapat dilakukan mulai dari Pendidikan Anak Dini Usia (PADU) sampai pada orang dewasa pada jenjang keaksaraan Fungsional, Kesetaraan, Pendidikan wanita, dan juga Kursus.

Salah satu lembaga pendidikan nonformal yang mengadakan pendidikan kecakapan hidup yaitu LKP AR-RUM. LKP ini diharapkan mampu membantu masyarakat dalam mengatasi masalah kesulitan dalam memasuki dunia kerja. Program yang diadakan oleh LKP AR-RUM antara lain menjahit, membordir, mendesain, dan membatik. Pelatihan yang banyak diminati oleh masyarakat yaitu pelatihan menjahit karena saat ini makin banyaknya tuntutan kerja yang membutuhkan jasa dibidang menjahit ini. Pendidikan kecakapan hidup menjahit ini dapat menjadikan lulusan sebagai asisten menjahit, profesional dibidang tata busana, dan dapat berwirausaha dibidang tata busana. Peserta didik lulusan LKP AR-RUM tidak semuanya dapat tertampung pada lapangan kerja, karena LKP hanya menyiapkan peserta didik yang siap bekerja bukan menyiapkan lapangan kerja untuk mereka. Pendidikan Kecakapan Hidup menjahit ini peserta didik diharapkan dapat memasuki dunia pekerjaan yang sesuai dengan bidangnya dan juga dapat berwirausaha mandiri.

Belajar wirausaha dalam kondisi kehidupan yang serba ketat menuntut untuk mampu menguasai beberapa keterampilan yang aplikatif. Keterampilan menjahit inilah yang selanjutnya dijadikan bekal menghadapi hidup sehingga mampu menghadapi kehidupan dimasyarakat. Hal ini sangatlah penting sebab kemampuan itu yang menjadikan peserta didik survive dalam hidupnya. Wirausaha berperan secara baik dalam pertumbuhan perekonomian, wirausaha secara internal maupun eksternal berperan dalam mengurangi pengangguran dan ketergantungan pada orang lain. Secara internal seorang wirausaha dapat meningkatkan kepercayaan dirinya serta dapat meningkatkan nilai tambah untuk dirinya, secara eksternal 
Diklus: Jurnal Pendidikan Luar Sekolah, 1(1), Maret 2017 - 68

Anggrita Kusumaninggar

wirausaha dapat menyediakan lapangan kerja bagi orang yang sedang mencari kerja. Dengan hal tersebut maka jumlah pengangguran akan berkurang dan permasalahan pengangguran dapat teratasi sehingga pendapatan yang dihasilkan juga dapat bertambah.

Dari masalah masalah diatas maka peneliti bermaksud untuk meneliti bagaimana Dampak Pelaksanaan Pendidikan Kecakapan Hidup Menjahit terhadap Aktivitas Wirausaha Warga Belajar di LKP AR-RUM.

\section{METODE PENELITIAN}

Jenis Penelitian

Penelitian ini dilakukan dengan metode deskriptif kualitatif yaitu dengan cara memandang objek penelitian sebagai suatu sistem, yaitu artinya objek kajian dapat dilihat sebagai satuan yang terdiri dari unsur yang saling terkait dan mendeskripsikan fenomena yang ada.

\section{Subyek Penelitian}

Subyek penelitian Pengelola, instruktur menjahit, dan warga belajar LKP AR-RUM yang aktif mengikuti program pelatihan menjahit.

\section{Setting dan Waktu Penelitian}

Penelitian ini dilakukan di LKP ARRUM dan di rumah warga belajar LKP ARRUM dengan pertimbangan peneliti dapat mengamati secara langsung kegiatan pembelajaran dan kegiatan peserta didik pasca program pelatihan. Penelitian dilaksanakan pada bulan April 2016 sampai dengan bulan Juli 2016.

\section{Teknik Pengumpulan Data}

Penelitian ini bersifat deskriptif berupa dokumen pribadi, catatan harian, catatan lapangan, ataupun ucapan responden dari hasil wawancara. Instrumen dalam penelitian ini yaitu peneliti sendiri yang dibantu oleh pedoman wawancara, observasi dan dokumentasi. Teknik pengumpulan data yang digunakan adalah observasi, wawancara dan dokumentasi.

\section{Teknik Analisis Data}

Tahapan analisis data dalam penelitian ini yaitu reduksi data, display data dan penarikan kesimpulan. Reduksi data dimaksudkan dengan merangkum data, memilih hal-hal pokok, disusun secara sistematik display data atau penyajian data bertujuan untuk memudahkan peneliti memahami hasil penelitian yang telah didapatkan. Data tersebut dibandingkan dan dihubungkan dengan yang lainnya, sehingga mudah ditarik kesimpulan sebagai jawaban dari setiap permasalahan yang ada.

\section{HASIL DAN PEMBAHASAN}

Pelaksanaan Program Pendidikan Kecakapan Hidup Kursus Menjahit di LKP AR-RUM.

a. Pelaksanaan Program Pendidikan Kecakapan Hidup Kursus Menjahit di LKP AR-RUM 


\section{Diklus: Jurnal Pendidikan Luar Sekolah, 1(1), Maret 2017 - 69 \\ Anggrita Kusumaninggar}

Program pendidikan kecakapan hidup ini diselengarakan dalam rangka untuk pemberdayaan masyarakat agar memiliki kemampuan mengembangkan potensi dirinya khususnya dibidang keterampilan menjahit. Program Pendidikan Kecakapan Hidup Menjahit dilaksanakan di LKP ARRUM Yogyakarta.

b. Pembelajaran pendidikan kecakapan hidup menjahit di LKP AR-RUM

Materi umum yaitu teori mengenai pentingnya pendidikan kecakapan hidup. Sementara materi pokok yaitu pengenalan garis-garis pokok pola, pengambilan ukuran badan, pola dasar baju wanita, pola blus, pola rok, gamis, dan Kebaya. Proses pembelajaran dimulai sejak pukul 09.0011.00 WIB

\section{Hasil Pelaksanaan Program Pendidikan} Kecakapan Hidup Menjahit Terhadap Aktivitas Wirausaha Warga Belajar di LKP AR-RUM

a. Peningkatan Pengetahuan Warga Belajar Mengenai Menjahit Setelah mengikuti Program Pendidikan Kecakapan Hidup

Peningkatan pengetahuan menjahit warga belajar dapat dilihat saat pelatihan dan setelah pelatihan selesai. Peningkatan pengetahuan tersebut mampu digunakan sebagai tolak ukur dalam mengetahui keberhasilan program menjahit. Mengetahui peningkatan pengetahuan dengan cara mengukur tingkat teori pengetahuan menjahit warga belajar yang dilakukan secara lisan dan praktik.

b. Hasil Produk Warga Belajar Setelah Mengikuti Pelatihan Menjahit

Produk merupakan hasil dari suatu program pembelajaran, bila program pembelajaran berjalan dengan efektif dan efisien. Hasil produk menjahit mampu menjadi tolak ukur dalam menilai seperti apa keberhasilan dari program pelatihan menjahit. Hasil produk warga belajar meliputi blus, kemeja, rok, gamis dan kebaya.

c. Kecakapan Personal yang dimiliki Warga Belajar Setelah Mengikuti Program Pelatihan Menjahit

Setelah selesai mengikuti program, warga belajar mampu melihat kelebihan dan kekurangan yang dimiliki. Hal tersebut bertujuan sebagai acuan warga belajar untuk lebih bersemangat lagi dalam menuntut ilmu dalam hal menjahit. Selain mengetahui kelebihan dan kekurangan, warga belajar juga harus mampu percaya diri. Kecakapan personal juga mencakup rasa percaya diri yang dimiliki oleh diri sendiri.

d. Kecakapan Sosial yang Dimiliki Warga Belajar Setelah Menikuti Pelatihan Menjahit 


\section{Diklus: Jurnal Pendidikan Luar Sekolah, 1(1), Maret 2017 - 70 \\ Anggrita Kusumaninggar}

Cara yang dilakukan oleh LKP ARRUM dalam menumbuhkan sikap berwirausaha yaitu dengan memberikan fasilitas kepada warga belajar agar mereka nantinya mampu menghasilkan produk yang lebih beragam dan mampu bersaing dengan penjahit lainnya.

e. Kecakapan Akademik yang Dimiliki warga belajar setelah mengikuti pelatihan menjahit

Warga belajar mampu melakukan identifikasi kebutuhan sehingga mampu melakukan tindakan penyeleseaian. kecakapan akademik yang berupa berfikir ilmiah sudah mampu diterapkan dalam diri warga belajar meskipun masih ada yang masih ragu akan kemampuan akademiknya, seluruh warga belajar yang mengikuti program pendidikan kecakapan hidup menjahit dikatakan lulus.

f. Kecakapan Vokasional yang dimiliki warga belajar setelah mengikuti pelatihan menjahit

Kecakapan vokasional warga belajar dalam aktivitas wirausaha menjahit, warga belajar semakin bersemangat dalam merintis usaha menjahit berkat pengetahuan yang diperoleh setelah mengikuti kursus menjahit yang diselenggarakan LKP AR-RUM.

Dampak Program Pendidikan Kecakapan Hidup Menjahit Terhadap Aktivitas Wirausaha Warga Belajar di LKP AR-RUM a. Dampak Ekonomi Warga Belajar Setelah mengikuti Program Pendidikan Kecakapan Hidup Menjahit

Dampak program keterampilan menjahit secara ekonomi belum terlihat maksimal karena hanya mengurangi pengeluaran tetapi tidak adanya pemasukan. Dampak ekonomi biasanya dilihat dari peningkatan penghasilan yang diperoleh oleh warga belajar. Jadi dapat disimpulkan bahwa dampak ekonomi belum terlihat maksimal.

b. Dampak Sosial Warga Belajar Setelah Mengikuti Program Pendidikan Kecakapan Hidup Menjahit

Dampak sosial program pendidikan kecakapan hidup menjahit bagi warga belajar berkaitan dengan perubahan perilaku, keterampilan, pengetahuan, sikap, status atau perubahan kehidupan terhadap hubungan dan interaksi sosial warga belajar terhadap orang lain dan masyarakat luas.

\section{Faktor Yang Mempengaruhi Program Pendidikan Kecakapan Hidup Menjahit terhadap Aktivitas Wirausaha Warga \\ Belajar di LKP AR-RUM}

a. Faktor Pendorong dan Penghambat Pembelajaran Kursus Menjahit

Faktor pendukung pelatihan pkh menjahit adalah tersedia sarana dan prasarana pembelajaran yang lengkap, instruktur yang berpengalaman,situasi dan lingkungan yang kondusif, adanya motivasi 


\section{Diklus: Jurnal Pendidikan Luar Sekolah, 1(1), Maret 2017 - 71 \\ Anggrita Kusumaninggar}

dan kemampuan warga belajar dalam pembelajaran yang besar. Faktor penghambatnya yaitu usia warga belajar berbeda-beda, kemampuan instruktur yang kurang maksimal.

b. Faktor yang mendorong warga belajar untuk mengikuti pembelajaran keterampilan menjahit

faktor pendorong warga belajar yaitu adanya dukungan keluarga, motivasi belajar tinggi, cara mengajar mudah dipahami warga belajar, adanya sertifikat setelah warga belajar lulus dari program pendidikan kecakapan hidup menjahit.

\section{PEMBAHASAN}

Pelaksanaan Program Pendidikan Kecakapan Hidup Menjahit di LKP ARRUM.

Program pendidikan kecakapan hidup ini diselengarakan dalam rangka untuk pemberdayaan masyarakat agar memiliki kemampuan mengembangkan potensi dirinya khususnya dibidang keterampilan menjahit. Pendidikan kecakapan hidup ini dilaksanakan pada bulan April-Juli 2016 selama 24X pertemuan. Pendidikan kecakapan hidup menjahit yang dilaksanakan di LKP AR-RUM Yogyakarta. Materi yang diajarkan bersifat umum dan pokok. Proses pembelajaran dimulai sejak pukul 09.00-11.00 WIB. Tindak lanjut dari pelaksanaan program pendidikan kecakapan hidup menjahit yaitu peserta dapat melaksanakan kegiatan usaha secara berkelompok atau individu.

\section{Hasil Pelaksanaan Program Pendidikan Kecakapan Hidup Menjahit Terhadap Aktivitas Wirausaha Warga Belajar di LKP AR-RUM.}

Hasil program pendidikan kecakapan hidup menjahit mencakup peningkatan pengetahuan, hasil produk, kecakapan personal, kecakapan sosial, kecakapan akademik dan kecakapan vokasional warga belajar. Peningkatan pengetahuan yang dimiliki warga belajar setelah mereka mengikuti pelatihan menjahit yaitu cara mengambil ukuran, cara membuat pola, dan teori tentang menjahit. Contoh produk yang dihasilkan warga belajar setelah program pelatihan menjahit selesai antara lain kemeja, blus, rok, gamis, kebaya, dan juga lain-lain. Kecakapan personal warga belajar setelah mengikuti pelatihan menjahit semakin meningkat. Bukti nyata peningkatan kecakapan personal yang diperoleh warga belajar setelah mengikuti pelatihan menjahit yaitu peningkatan rasa percaya diri dalam menumbuhkan jiwa wirausaha, dan mampu mengetahui kelebihan serta kekurangan yang dimiliki. Kecakapan sosial yang dimiliki warga belajar setelah mengikuti pelatihan menjahit yaitu kecakapan berkomunikasi dan bekerjasama. Kecakapan akademik warga belajar setelah mengikuti pelatihan yaitu mereka mendapatkan nilai yang 


\section{Diklus: Jurnal Pendidikan Luar Sekolah, 1(1), Maret 2017 - 72 \\ Anggrita Kusumaninggar}

memuaskan. Nilai tersebut mampu digunakan sebagai motivasi untuk membuka sebuah usaha jahit.

\section{Dampak Program Pendidikan Kecakapan Hidup Menjahit terhadap Aktivitas Wirausaha Warga Belajar Di LKP AR- RUM}

Dampak adalah gambaran mengenai nilai suatu program. Dampak mengacu pada manfaat jangka panjang terhadap masyarakat seperti peningkatan pengetahuan, efisiensi produksi, peningkatan lingkungan hidup, keuntungan finansial dan sebagainya. Dampak ekonomi program pelatihan kecakapan hidup menjahit dapat dirasakan langsung oleh masyarakat. Dibuktikan dengan jumlah pengeluaran keuangan mulai berkurang, dana yang digunakan untuk membeli pakaian, sekarang sudah mulai berkurang karena mampu membuat pakaian sendiri yang sesuai dengan selera setiap warga belajar. Dampak sosial pelatihan menjahit yaitu peningkatan status sosial, peningkatan kepedulian sosial, dan peningkatan kemampuan membelajarkan ilmu kepada orang lain. Kecakapan sosial yang diperoleh warga belajar dalam pembelajaran pelatihan menjahit merupakan bekal bagi warga belajar untuk meningkatkan kemampuan sosialnya dalam berhubungan dan berinteraksi dengan orang lain dan masyarakat luas. Jadi dapat dikatakan dampak sosial yang dimiliki warga belajar ada dan diterapkan dalam kehidupannya.

\section{Faktor Yang Mempengaruhi Program Pendidikan Kecakapan Hidup Menjahit Terhadap Aktivitas Wirausaha Warga Belajar di LKP AR-RUM}

Faktor pendorong pendidikan kecakapan hidup menjahit yaitu adanya ketersediaan sarana dan prasarana yang lengkap, tersedianya instruktur yang berpengalaman dalam kegiatan pembelajaran, adanya motivasi dari dalam diri warga belajar sendiri untu mengikuti pelatihan menjahit, dan adanya dukungan dari berbagai pihak terkait dalam mengikuti pelaksanaan program pendidikan kecakapan hidup menjahit.

Faktor penghambat dalam proses pendidikan kecakapan hidup menjahit juga ada. Faktor-faktor tersebut antara lain usia warga belajar yang berbeda-beda sehingga menghambat proses pembelajaran, kemampuan instruktur yang kurang maksimal, pengetahuan dan kemampuan warga belajar yang berbeda.

\section{KESIMPULAN DAN SARAN KESIMPULAN}

1. Pelaksanaan Program Pendidikan Kecakapan Hidup Menjahit di LKP AR-RUM

Program Pendidikan Kecakapan Hidup Menjahit diselenggarakan berdasarkan masih rendahnya SDM masyarakat disekitar lembaga maupun di Kota Yogyakarta, dan diselengarakan dalam rangka untuk pemberdayaan masyarakat agar memiliki 


\section{Diklus: Jurnal Pendidikan Luar Sekolah, 1(1), Maret 2017 - 73 \\ Anggrita Kusumaninggar}

kemampuan mengembangkan potensi dirinya khususnya dibidang menjahit. Pendidikan kecakapan hidup dilaksanakan pada bulan April-Juli 2016 selama 24X pertemuan. Pendidikan kecakapan hidup menjahit yang dilaksanakan di LKP AR-RUM Yogyakarta. Tindak lanjut pelaksanaan program pendidikan kecakapan hidup menjahit yaitu peserta dapat melaksanakan kegiatan usaha secara berkelompok atau individu.

2. Hasil program pedidikan kecakapan hidup menjahit mencakup peningkatan pengetahuan, hasil produk, kecakapan sosial, kecakapan akademik dan kecakapan vokasional. Peningkatan pengetahuan yang dimiliki warga belajar yaitu cara mengambil ukuran, membuat pola, dan teori tentang menjahit. Hasil produk yang dibuat oleh warga belajar yaitu membuat blus, gamis, rok dan kebaya. Setelah mengikuti program pelatihan menjahit warga belajar memperoleh peningkatan rasa percaya diri dalam menumbuhkan jiwa wirausaha, dan mampu mengetahui kelebihan serta kekurangan yang dimilikinya. Kecakapan sosial yang dimiliki warga belajar yaitu kecakapan berkomunikasi dan bekerjasama. Dengan mengetahui cara mengambil ukuran, membuat pola, dan menjahit dengan benar mampu digunakan sebagai motivasi untuk membuka usaha menjahit. kecakapan personal, sosial, dan akademik juga membuat kecakapan vokasional warga belajar meningkat.

3. Dampak pelaksanaan program pendidikan kecakapan hidup menjahit terhadap aktivitas wirausaha warga belajar di LKP AR-RUM. Dampak ekonomi dapat dirasakan langsung, dibuktikan dengan jumlah pengeluaran keuangan mulai berkurang. Dampak sosial pelatihan menjahit yaitu peningkatan kemampuan membelajarkan ilmu kepada orang lain.

4. Faktor yang mempengaruhi pelaksanaan program pendidikan kecakapan hidup menjahit terhadap aktivitas wirausaha warga belajar di LKP AR-RUM. Faktor pendorong pendidikan kecakapan hidup menjahit yaitu :

a. tersedianya sarana dan prasarana yang lengkap

b. Tersedianya instruktur yang berpengalaman

c. Situasi yang kondusif dan menyenangkan

d. Adanya motivasi dari dalam diri warga belajar

e. Adanya dukungan dari berbagai pihak terkait

faktor penghambat, antara lain:

a. Usia warga belajar berbeda

b. Kemampuan instruktur kurang maksimal

c. Pengetahuan warga belajar yang berbeda

\section{SARAN}




\section{Diklus: Jurnal Pendidikan Luar Sekolah, 1(1), Maret 2017 - 74 \\ Anggrita Kusumaninggar}

1. Bagi Pengelola

a. Perlu adanya pola pembinaan dan pemantauan yang dilakukan oleh pihak LKP AR-RUM secara berkala untuk melihat secara mendalam kesulitan yang dialami warga belajar setelah program pelatihan selesai. b. Program pendidikan kecakapan hidup menjahit sebaiknya ditambah materi mengenai kewirausahaan.

\section{DAFTAR PUSTAKA}

Sisdiknas. (2003). Undang- Undang RI No. 20 Tahun 2003 Tentang Sistem Pendidikan Nasional. Jakarta

www.bps.go.id. Di unduh pada tanggal 10 Januari 2016 pukul 14:09 WIB 